\title{
Őszi káposztarepce N-, C- és S-tartalmának alakulása N-trágyázás hatására mészlepedékes csernozjom talajon
}

\author{
${ }^{1}$ MÁTHÉNÉ GÁSPÁR GABRIELLA, ${ }^{1}$ RADIMSZKY LÁSZLÓ, \\ ${ }^{2}$ GYÖRI ZOLTÁN, ${ }^{3}$ HÜVELY ATTILA és ${ }^{1}$ NÉMETH TAMÁS \\ ${ }^{1}$ MTA Talajtani és Agrokémiai Kutatóintézet, Budapest; ${ }^{2}$ DE ATC MTK \\ Mezőgazdasági Termékfeldolgozás és Minősítés Tanszék, Debrecen és \\ ${ }^{3}$ Kecskeméti Főiskola, Kertészeti Főiskolai Kar, Kecskemét
}

A mérsékelt égövön elterjedten termesztett öszi káposztarepce (Brassica napus L. subsp. napus) Magyarország második legfontosabb olajnövénye, melynek számos tanulmányból ismert nagy N-igénye (NÉMETH \& KARAMÁN, 1986; NÉMETH, 1987-1988, 1988; HoCKING et al., 1997; KÁDÁR et al., 2001; KÁDÁR, 2002) és jelentős S-igénye (MCGRATH \& ZHAO, 1997; SCHNUG \& HANEKLAUS, 1998; SCHERER, 2001).

Irodalmi áttekintésünk csak a repce S-tartalmára vonatkozik, tekintettel az e folyóiratban korábban megjelent számos N-tartalommal és N-ellátottsággal foglalkozó írásra.

A kén a nitrogénhez hasonlóan nemcsak fehérje alkotó, de fontos szerepe van a fehérje és az olajszintézis enzimrendszerében is. Vizsgálata az utóbbi években az ipar S-kibocsátásának csökkenésével párhuzamosan, elsősorban a nyugat-európai országokban és Ausztráliában került előtérbe. Az intenzív növénytermesztés a mütrágyával pótolt fő tápelemek ( $\mathrm{N}, \mathrm{P}$ és $\mathrm{K})$ mellett ugyanis a kén nagymértékủ kivonásával, és ennek következtében, különösen a ként kevésbé megkötő talajokon, a Startalom csökkenésével és növényi hiánytünetekkel jár (MENGEL, 1976; CECOTTI, 1996; SCHERER, 2001). A nagy S-igényü növények, így a repce is, ezért a talajok Sellátó képességének jellemzésére is alkalmasak.

A növények tápanyagellátásának ellenőrzésére leggyakrabban a levél elemtartalma használatos. Elégtelen a repce S-ellátása akkor, ha a levél S-tartalma $6,5 \mathrm{mg} / \mathrm{g}$ alatti. Vizuális hiánytüneteket a növény $3-3,5 \mathrm{mg} / \mathrm{g}$ alatt mutat, míg e felett 6,5 $\mathrm{mg} / \mathrm{g}$-ig ún. rejtett hiánytünetek jelentkeznek (SCHNUG \& HANEKLAUS, 1998). A Shiány tünetei hasonlóak a N-hiány tüneteihez, ezért egyértelmü kimutatásához a N/S arány meghatározása is nélkülözhetetlen. SALBACH (1972) szerint a különbözö növényfajok kritikus arányai a levélben 10 körüli értékek (10,4-14).

A repcenövény N- és S-anyagcseréje egymással szoros kapcsolatban van. A vonatkozó irodalmi adatok szerint a N-trágyázás hatására többnyire csökken ugyan a növény összes-S-tartalma (JANZEN \& BETTANY, 1984; SUNARPI \& ANDERSON,

Postai cím: MÁTHÉNÉ GÁSPÁR GABRIELLA, MTA Talajtani és Agrokémiai Kutatóintézet, 1022 Budapest, Herman Ottó út 15.E-mail: ggabi@rissac.hu 
1997; FISMES et al., 2000), azonban a szerves-S mennyisége nő (BLOEM et al., 2004). A S-kimosódásra hajlamos, humuszban szegény talajokon a S-trágyázás fokozza a nitrogén termésnövelő hatását, emellett a termés minőségét is javítja (MCGRATH \& ZhaO, 1997; SChNUG \& HANEKLAUS, 1998; Fismes et al., 2000; SCHERER, 2001).

$\mathrm{Az}$ előzmények ismeretében a repce okszerü tápanyagellátását célzó Ntrágyázási tartamkísérlet 2003-2004. évi vizsgálatait a S-tartalom és a N/S arány alakulására is kiterjesztettük. A repce mennyiségi és minőségi változásainak jelzőjeként előzőeken túl a $\mathrm{C}$-tartalmat, továbbá a $\mathrm{C} / \mathrm{N}$ arányt is jellemeztük.

\section{Anyag és módszer}

A kísérletet Nagyhörcsökön mészlepedékes csernozjom talajon végeztük 20032004-ben. Az elemzett repcekísérlet egy 1985-ben indított N-trágyázási tartamkísérlet része, melyben az alparcellák kialakítására négyévenként kerül sor. A repce (GK-Gabriella) vetése 2003. szept. 8-án, betakarítása 2004. júl. 12-én történt. A Nadagok felét vetés előtt (2003. aug. 21-én) alaptrágyaként a P- és K-trágyával (100$100 \mathrm{~kg} / \mathrm{ha}$ ) együtt, felét tavasszal (2004. ápr. 5-én) fejtrágyaként juttattuk ki. Az őszi N-adagok a kísérlet föparcelláin (jelölésük 1-4): 0, 75, 150 és $225 \mathrm{~kg} \mathrm{~N} / \mathrm{ha}$, a tavasziak pedig a föparcellán kialakított alparcellákon (jelölésük 1-5): 0, 50, 100, 150 és $200 \mathrm{~kg} \mathrm{~N} /$ ha voltak. Az őszi kezelés a kontrollal együtt négy, a tavaszival együtt pedig már húsz N-szintet jelentett.

A kísérlet indulása előtt az elemtartalmat a felső talajréteg $(0-20 \mathrm{~cm})$ átlagmintájából - az ún. „összes elemtartalmát” királyvizes oldást, „,könnyen oldható elemtartalmát” pedig ammónium-acetát+EDTA (LAKANEN \& ERVIÖ, 1971) oldást követően - ICP-vel határoztuk meg. A talaj felső rétegének általános fizikai-kémiai jellemzői a kontrollparcellában a következők voltak: humusztartalom 2,95\%; pH(KCl) 7,41; $\mathrm{CaCO}_{3}$ 9,46 \%; kötöttség $\left(\mathrm{K}_{\mathrm{A}}\right)$ 40; sótartalom $<0,02 \%$; az összes-Ntartalom $1910 \mathrm{mg} / \mathrm{kg}$, P-tartalom $1048 \mathrm{mg} / \mathrm{kg}$, K-tartalom $5148 \mathrm{mg} / \mathrm{kg}$, míg a Startalom $300 \mathrm{mg} / \mathrm{kg}$ volt.

A repce trágyázása előtt (2003. aug. 19.) a tartamkísérlet föparcelláin $1 \mathrm{~m}$ talajmélységig $20 \mathrm{~cm}$-es rétegenként vett mintákból (KCl-os kivonással) meghatároztuk a $\mathrm{NO}_{3}-\mathrm{N}$ - és $\mathrm{NH}_{4}-\mathrm{N}$-tartalmat. Megállapítható volt, hogy a kísérlet indulásakor a föparcellák talaja már jelentősen különbözött, elsősorban $\mathrm{NO}_{3}-\mathrm{N}$-tartalmában. A korábbi évek $\mathrm{N}$-trágyázása a $\mathrm{NO}_{3}-\mathrm{N}$ mennyiségét látványosan növelte (átlagosan 2,3 mg/kg-ról a kezelések sorrendjében 10,4, 23,6 és 32,2 mg/kg-ra), ugyanakkor az $\mathrm{NH}_{4}-\mathrm{N}$ mennyisége alig változott (4,3 mg/kg-ról 5-6 mg/kg-ra nőtt).

A növényeket a repce főbb tavaszi-nyári fejlődési szakaszainak megfelelő időpontokban, tavaszi tőrózsás állapot végén, szárbaindulás kezdetén, virágzás kezdetén és éréskor mintáztuk. A tavasz folyamán a növényállományból a föparcelláknak (ápr. 19-én), majd az alparcelláknak megfelelően (ápr. 22-én és máj. 3-án) átlagmintát vettünk (20 minta). Betakarításkor (2004. július 12-én) mindegyik alparcella növényeit ismétlésenként külön kezeltük (80 minta). A növények föld feletti részét levágtuk, a talajszennyezéseket csapvizes öblítéssel eltávolítottuk, majd $\left(40-50{ }^{\circ} \mathrm{C}\right.$ - 
on) légszárazra szárítottuk. Elkülönítettük a szárat a levéltől, ill. bimbózás után a levéltől és a virágzattól, végül betakarításkor megállapítottuk a mintakéve termésés szalmatömegét, továbbá a nettó parcella $\left(21 \mathrm{~m}^{2}\right)$ teljes magtermését.

A növényminták szárazanyag-tartalmát gravimetriásan, N-, C- és S-tartalmát pedig az ICC által ajánlott standard módszerrel határoztuk meg (ICC standard No. 167, 2000).

A repce tápanyagfelvételében az időjárási tényezők közül hazánkban többnyire a csapadék szerepe a meghatározó. 2003 őszén a kelés, míg 2004 májusában a termésképzés szempontjából kedvezőtlenül, hosszabb száraz időszak volt.

Az adatok statisztikai értékeléséhez egy- és többtényezős varianciaanalízist alkalmaztunk, meghatároztuk az átlagértékeket és a 95\%-os valószínüségü szignifikáns differenciát.

\section{Eredmények}

\section{A növény tömegének alakulása}

A tavaszi fejlődés és növekedés során, a repce $\mathrm{N}$-igényének növekedésével a $\mathrm{N}$ kezelés hatására megbízhatóan nőtt a növény föld feletti részeinek tömege (1. táblázat). Az intenzív szárnövekedés a levél arányának erőteljes csökkenésével (74\%-ról 30\%-ra) párosult.

Kísérletünkben a föparcella, mint kezelési egység, együttesen tükrözte a tartamkísérletben korábban adott és a repcére kijuttatott őszi N-trágya hatását, és határozta meg a fejtrágya hatásosságát. A N-fejtrágyázás hatására a magtermés csupán az 1. és 2. föparcellán nőtt megbízhatóan, látványos emelkedést pedig csak az 1. föparcellán mutatott (2. táblázat). A kontrollparcella 0,65 t/ha magtermését a legnagyobb fejtrágyaadagok ugyanúgy 2 t/ha-ra növelték, mint fejtrágyázás nélkül a jó $\mathrm{N}$ ellátást biztosító 3. és 4 . föparcellákét.

A talaj növekvő $\mathrm{NO}_{3}$-tartalmának megfelelően egyre kisebb mütrágyaadag kijuttatásával értünk el maximális termést. Így az 1. föparcellán $200 \mathrm{~kg} \mathrm{~N} / \mathrm{ha}$, a 2. fôpparcellán $175 \mathrm{~kg} \mathrm{~N} / \mathrm{ha}$, a 3. föparcellán pedig $150 \mathrm{~kg} \mathrm{~N} / \mathrm{ha}$ adagnál egyaránt $2 \mathrm{t} / \mathrm{ha}$

\section{1. táblázat}

Az őszi káposztarepce hajtástömegének alakulása a főparcellákon (1-4.) N-trágyázás hatására a tavaszi-nyári mintavételek során (Nagyhörcsök)

\begin{tabular}{|c|c|c|c|c|c|c|c|}
\hline \multirow{2}{*}{$\begin{array}{c}\text { (1) } \\
\text { Mintavétel } \\
\text { ideje } \\
\text { (év, hó, nap) }\end{array}$} & \multirow{2}{*}{$\begin{array}{l}\text { A repce fejlődési } \\
\text { állapota }\end{array}$} & \multicolumn{6}{|c|}{$\begin{array}{l}\text { (3) Légszáraz hajtástömeg a föparcellákon, } \\
\qquad \mathrm{g} / 10 \mathrm{db}\end{array}$} \\
\hline & & 1. & 2. & 3. & 4. & Átlag & $\begin{array}{c}(5) \\
\mathrm{SzD}_{5 \%}\end{array}$ \\
\hline 2004. 04. 19. & a) tőrózsás állapot vége & 28 & 34 & 37 & 33 & 33 & 3,6 \\
\hline 2004. 04. 22. & b) szárbaindulás kezdete & 33 & 41 & 49 & 40 & 41 & 11,8 \\
\hline 2004.05 .03$. & c) virágzás kezdete & 76 & 94 & 106 & 103 & 95 & 18,0 \\
\hline 2004. 07. 12 . & d) érés vége & 82 & 146 & 142 & 155 & 131 & 27,1 \\
\hline
\end{tabular}




\section{2. táblázat}

Az őszi káposztarepce magtermésének (t/ha) alakulása a különböző N-adagoknál

\begin{tabular}{|c|c|c|c|c|c|}
\hline \multirow{2}{*}{\multicolumn{2}{|c|}{$\begin{array}{c}1) \\
\text { Alparcellák és a tavasszal } \\
\text { kijuttatott } \mathrm{N} \text {-adagok }\end{array}$}} & \multicolumn{4}{|c|}{ (2) Főparcellák és az ősszel kijuttatott N-adagok } \\
\hline & & $\begin{array}{c}1 . \\
0 \mathrm{~kg} \mathrm{~N} / \mathrm{ha}\end{array}$ & $\begin{array}{c}2 . \\
75 \mathrm{~kg} \mathrm{~N} / \mathrm{ha}\end{array}$ & $\begin{array}{c}3 . \\
150 \mathrm{~kg} \mathrm{~N} / \mathrm{ha}\end{array}$ & $\begin{array}{c}4 . \\
225 \mathrm{~kg} \mathrm{~N} / \mathrm{ha}\end{array}$ \\
\hline 1. & $0 \mathrm{~kg} \mathrm{~N} / \mathrm{ha}$ & 0,65 & 1,88 & 2,10 & 2,00 \\
\hline 2. & $50 \mathrm{~kg} \mathrm{~N} / \mathrm{ha}$ & 1,24 & 1,96 & 2,04 & 2,11 \\
\hline 3. & $100 \mathrm{~kg} \mathrm{~N} / \mathrm{ha}$ & 1,64 & 2,10 & 2,24 & 2,02 \\
\hline 4. & $150 \mathrm{~kg} \mathrm{~N} / \mathrm{ha}$ & 1,86 & 2,04 & 2,10 & 2,01 \\
\hline 5. & $200 \mathrm{~kg} \mathrm{~N} / \mathrm{ha}$ & 2,03 & 1,99 & 2,14 & 1,92 \\
\hline \multicolumn{2}{|c|}{ a) $\mathrm{SzD}_{5 \%}$} & \multicolumn{4}{|c|}{0,25} \\
\hline
\end{tabular}

körüli volt a termés. A termésgörbe a $375 \mathrm{~kg} / \mathrm{ha}$ N-szintig gyakorlatilag változatlan maradt, majd a legnagyobb N-adagnál (4/5. kezelés, összesen $425 \mathrm{~kg} \mathrm{~N} /$ ha trágya) enyhe termésdepresszió jelentkezett.

\section{A növény $N$-, C-és S-tartalmának alakulása a vegetatív szakaszokban}

A tőrózsás állapot végén (2004. ápr. 19-én) a repce föld feletti részeinek Ntartalma, e fejlődési szakaszra jellemzően magas (a szárban átlagosan 5,1\%, a levélben pedig 5,6\%) volt (3. táblázat). A két növényi rész $\mathrm{N}$-tartalma csak az 1 . (kontroll) főparcellán volt szignifikánsan alacsonyabb. A magas N-tartalomhoz magas S-tartalom társult, azonban a N-tartalomtól eltérően jelentős volt a növényi részek különbsége. A levél 1,05\%-os S-tartalma csaknem kétszerese volt a szár értékének $(0,6 \%)$.

A szárbaindulás szakaszát a repce erőteljes tömegnövekedése (1. táblázat), s ezzel párhuzamosan az elemtartalmak gyors változása jellemezte (3. táblázat). Mindössze 4 nap alatt (ápr. 19-22. között) a két növényi rész N-tartalma a korábbi minta értékeihez viszonyítva 9\%-kal, S-tartalma pedig 6\%-kal csökkent, melyhez a szárban a C-tartalom enyhe növekedése társult.

A virágzás kezdetén is jellemzően magasabb volt a repcelevél $\mathrm{N}-(4,3 \%)$ és $\mathrm{S}$ tartalma $(0,97 \%)$, mint a száré $(\mathrm{N}: 2,99 \%, \mathrm{~S}$ : 0,5\%). Az április 19-i minta elemtartalmához képest a levél N-tartalma 23\%-kal, a száré 41\%-kal, míg S-tartalmuk csupán 8 , ill. 19\%-kal csökkent.

A repce elemtartalma - a N-trágyázatlan kontrollparcella $\mathrm{N}$-tartalma kivételével $(3,14 \% \mathrm{~N})$ - mindkét elemre vonatkozóan megfelelö volt, hiszen meghaladta a levélre megadott határértékeket $(\mathrm{N}:>3,3 \%, \mathrm{~S}:>0,5 \%)$ (REUTER \& ROBINSON, 1997). Kísérletünk növénymintáinak N-tartalom értékei rendre hasonlóak KÁDÁR (2002) 20 évvel korábbi, szintén Nagyhörcsökön beállított repcekísérletének adataihoz.

A nitrogéntől és a kéntől eltérően a vegetatív fejlődés végét a két föld feletti vegetatív rész C-tartalmának közeledése, a szár C-tartalmának növekedése jellemezte (a levélben 37,7\%, a szárban 38,7\%). 


\section{3. táblázat}

N-kezelés hatása a repce föld feletti részeinek elemtartalmára a tőrózsás állapot végén (A), a szárbaindulás (B) és a virágzás kezdetén (C) a föparcellákon

\begin{tabular}{|c|c|c|c|c|c|c|c|}
\hline \multirow[t]{2}{*}{$\begin{array}{l}(1) \\
\text { Elem }\end{array}$} & \multirow[t]{2}{*}{$\stackrel{(2)}{\text { Növényi rész }}$} & \multicolumn{4}{|c|}{$\begin{array}{l}\text { (3) Elemtartalom a N-kezelés hatására a } \\
\text { föparcellákon, \% }\end{array}$} & \multirow[t]{2}{*}{ Átlag } & \multirow[t]{2}{*}{$\begin{array}{c}(5) \\
\mathrm{SzD}_{5 \%}\end{array}$} \\
\hline & & 1. & 2. & 3. & 4. & & \\
\hline \multicolumn{8}{|c|}{ A. Törózsás állapot végén (2004. ápr. 19.) } \\
\hline \multirow[t]{2}{*}{$\mathrm{N}$} & a) szár & 4,5 & 5,1 & 5,5 & 5,5 & 5,1 & 1,0 \\
\hline & b) levél & 5,5 & 5,5 & 5,5 & 5,7 & 5,6 & 0,6 \\
\hline \multirow[t]{2}{*}{$\mathrm{C}$} & a) szár & 35,3 & 33,9 & 33,9 & 34,6 & 34,5 & 1,5 \\
\hline & b) levél & 39,3 & 38,6 & 38,2 & 38,4 & 38,6 & 1,5 \\
\hline \multirow[t]{2}{*}{$\mathrm{S}$} & a) szár & 0,7 & 0,6 & 0,6 & 0,6 & 0,6 & 0,2 \\
\hline & b) levél & 1,0 & 1,1 & 1,1 & 1,1 & 1,1 & 0,2 \\
\hline \multicolumn{8}{|c|}{ B. Szárbaindulás kezdetén (2004. ápr. 22.) } \\
\hline \multirow[t]{2}{*}{$\mathrm{N}$} & a) szár & 4,2 & 4,4 & 5,1 & 5,2 & 4,8 & 1,9 \\
\hline & b) levél & 4,8 & 5,2 & 5,0 & 5,3 & 5,1 & 1,3 \\
\hline \multirow[t]{2}{*}{$\mathrm{C}$} & a) szár & 37,3 & 36,0 & 35,6 & 35,4 & 36,1 & 2,9 \\
\hline & b) levél & 43,9 & 37,9 & 37,2 & 37,8 & 37,9 & 3,1 \\
\hline \multirow[t]{2}{*}{ S } & a) szár & 0,6 & 0,6 & 0,6 & 0,6 & 0,6 & 0,1 \\
\hline & b) levél & 0,9 & 1,0 & 1,0 & 1,0 & 1,0 & 0,4 \\
\hline \multicolumn{8}{|c|}{ C. Virágzás kezdetén (2004. máj. 3.) } \\
\hline \multirow[t]{2}{*}{$\mathrm{N}$} & a) szár & 2,3 & 3,3 & 3,2 & 3,1 & 3,0 & 0,5 \\
\hline & b) levél & 3,9 & 4,2 & 4,4 & 4,6 & 4,3 & 1,4 \\
\hline \multirow[t]{2}{*}{$\mathrm{C}$} & a) szár & 39,9 & 38,6 & 38,1 & 38,4 & 38,8 & 0,7 \\
\hline & b) levél & 38,2 & 37,5 & 36,9 & 38,1 & 37,7 & 1,2 \\
\hline \multirow[t]{2}{*}{$\mathrm{S}$} & a) szár & 0,5 & 0,6 & 0,5 & 0,5 & 0,5 & 0,0 \\
\hline & b) levél & 0,9 & 1,1 & 1,0 & 1,0 & 1,0 & 0,1 \\
\hline
\end{tabular}

\section{A növény $N$-, $C$ - és S-tartalmának alakulása betakaritáskor}

Betakarításkor a mag- és szalmatermés elemtartalma legjellemzőbben a Ntartalomban különbözött. A magtermés átlagosan 3,7\% N-tartalmával szemben a szalmáé csupán $0,98 \%$ volt (4. táblázat), tükrözve a nitrogén erőteljes átépülését a szárból a termésbe. A repceszár N-tartalmának tenyészidőszak alatti csökkenését közölte többek között NÉMETH (1988), KÁDÁR (2002), továbbá FISMES és munkatársai (2000). A növény N-ellátása szempontjából a szár szerepe kettős: tároló (,sink”) és forrás (,source”) is.

A N-tartalomnál kisebb mértékben, de statisztikailag megbízhatóan különbözött a szalma és a mag C- és S-tartalma. A C-tartalom jellemzően a magban, míg a Startalom a szalmában volt magasabb.

A C-tartalom a kor előrehaladtával nőtt, a szárban 34\%-ról 40,9\%-ra, legnagyobb értéket pedig a magtermésben, a raktározó komponensek növekedésével 


\section{4. táblázat}

N-trágyázás hatása az őszi káposztarepce mag- és szalmatermésének N-, C- és S-tartalmára betakarításkor (2004. július 12-én)

\begin{tabular}{|c|c|c|c|c|c|c|c|}
\hline \multirow{2}{*}{\multicolumn{2}{|c|}{$\begin{array}{c}(1) \\
\text { Alparcella és a } \\
\text { tavasszal kijuttatott } \\
\text { N-adag }\end{array}$}} & \multicolumn{2}{|c|}{$\mathrm{N}$-tartalom, $\%$} & \multicolumn{2}{|c|}{ C-tartalom, $\%$} & \multicolumn{2}{|c|}{ S-tartalom, $\%$} \\
\hline & & $\begin{array}{l}\text { (2) } \\
\text { Mag }\end{array}$ & $\begin{array}{c}\text { (3) } \\
\text { Szalma }\end{array}$ & $\begin{array}{l}\text { (2) } \\
\text { Mag }\end{array}$ & $\begin{array}{c}(3) \\
\text { Szalma }\end{array}$ & $\begin{array}{l}\text { (2) } \\
\text { Mag }\end{array}$ & $\begin{array}{c}\text { (3) } \\
\text { Szalma }\end{array}$ \\
\hline \multicolumn{8}{|c|}{ 1. Föparcella (0 kg N/ha összel) } \\
\hline 1. & $0 \mathrm{~kg} \mathrm{~N} / \mathrm{ha}$ & 3,60 & 0,57 & 43,9 & 52,8 & 0,66 & 0,52 \\
\hline 2. & $50 \mathrm{~kg} \mathrm{~N} / \mathrm{ha}$ & 3,34 & 0,56 & 47,2 & 49,4 & 0,61 & 0,55 \\
\hline 3. & $100 \mathrm{~kg} \mathrm{~N} / \mathrm{ha}$ & 3,33 & 0,73 & 50,5 & 46,1 & 0,53 & 0,61 \\
\hline 4. & $150 \mathrm{~kg} \mathrm{~N} / \mathrm{ha}$ & 3,43 & 0,77 & 53,8 & 42,6 & 0,49 & 0,67 \\
\hline 5. & $200 \mathrm{~kg} \mathrm{~N} / \mathrm{ha}$ & 3,61 & 0,85 & 57,0 & 41,0 & 0,43 & 0,71 \\
\hline \multicolumn{8}{|c|}{ 2. Föparcella (75 kg N/ha összel) } \\
\hline 1. & $0 \mathrm{~kg} \mathrm{~N} / \mathrm{ha}$ & 3,48 & 0,69 & 57,1 & 40,9 & 0,43 & 0,73 \\
\hline 2. & $50 \mathrm{~kg} \mathrm{~N} / \mathrm{ha}$ & 3,62 & 0,98 & 56,9 & 40,9 & 0,44 & 0,74 \\
\hline 3. & $100 \mathrm{~kg} \mathrm{~N} / \mathrm{ha}$ & 3,70 & 0,97 & 56,7 & 40,8 & 0,45 & 0,76 \\
\hline 4. & $150 \mathrm{~kg} \mathrm{~N} / \mathrm{ha}$ & 3,73 & 0,98 & 56,5 & 40,8 & 0,46 & 0,75 \\
\hline 5. & $200 \mathrm{~kg} \mathrm{~N} / \mathrm{ha}$ & 3,81 & 0,96 & 56,3 & 40,8 & 0,46 & 0,72 \\
\hline \multicolumn{8}{|c|}{ 3. Föparcella (150 kg N/ha összel) } \\
\hline 1. & $0 \mathrm{~kg} \mathrm{~N} / \mathrm{ha}$ & 3,74 & 1,06 & 56,2 & 40,9 & 0,46 & 0,70 \\
\hline 2. & $50 \mathrm{~kg} \mathrm{~N} / \mathrm{ha}$ & 3,82 & 1,06 & 56,1 & 41,0 & 0,46 & 0,70 \\
\hline 3. & $100 \mathrm{~kg} \mathrm{~N} / \mathrm{ha}$ & 3,82 & 1,20 & 56,1 & 41,0 & 0,45 & 0,69 \\
\hline 4. & $150 \mathrm{~kg} \mathrm{~N} / \mathrm{ha}$ & 3,82 & 1,06 & 56,1 & 41,1 & 0,45 & 0,68 \\
\hline 5. & $200 \mathrm{~kg} \mathrm{~N} / \mathrm{ha}$ & 3,82 & 1,16 & 56,1 & 41,1 & 0,44 & 0,68 \\
\hline \multicolumn{8}{|c|}{ 4. Föparcella (225 kg N/ha összel) } \\
\hline 1. & $0 \mathrm{~kg} \mathrm{~N} / \mathrm{ha}$ & 3,79 & 1,06 & 56,2 & 41,1 & 0,44 & 0,67 \\
\hline 2. & $50 \mathrm{~kg} \mathrm{~N} / \mathrm{ha}$ & 3,77 & 1,20 & 56,2 & 41,1 & 0,44 & 0,68 \\
\hline 3. & $100 \mathrm{~kg} \mathrm{~N} / \mathrm{ha}$ & 3,81 & 1,25 & 56,2 & 41,0 & 0,45 & 0,69 \\
\hline 4. & $150 \mathrm{~kg} \mathrm{~N} / \mathrm{ha}$ & 3,88 & 1,19 & 56,2 & 40,9 & 0,45 & 0,70 \\
\hline 5. & $200 \mathrm{~kg} \mathrm{~N} / \mathrm{ha}$ & 3,83 & 1,24 & 56,2 & 40,9 & 0,46 & 0,70 \\
\hline & $\mathrm{SzD}_{5 \%}$ & \multicolumn{2}{|c|}{0,05} & \multicolumn{2}{|c|}{0,3} & \multicolumn{2}{|c|}{0,05} \\
\hline
\end{tabular}

mutatott $(56,4 \%)$. A repce növekedése során a $\mathrm{C} / \mathrm{N}$ arány - a $\mathrm{N}$-tartalom egyidejü csökkenése miatt- a szárban mintegy hatszorosára nőtt, az áprilisi 6,56 értékröl (C: 33,96\%, N: 5,18\%) betakarítás idejére 41,78-ra (C: 40,9\%, N: 0,98\%). A C/N arány erőteljes változása a szárban főként az előbbiekben említett $\mathrm{N}$-átépülés következménye. A szár szervesanyag-összetétel változásai is (nyersfehérje csökkenés, nyersrost növekedés) - melyet egyéb növények korábbi vizsgálatakor leírtunk (MÁTHÉNÉ et al., 2001) - a C/N arányt elsősorban a $\mathrm{N}$-tartalmú vegyületek átépülésén keresztül módosítja. 
A N-trágyázás hatására ,általános" tendenciaként nőtt a repcemag N-tartalma. A görbe maximuma $3,82 \% \mathrm{~N}$-tartalomnál volt. Az összel N-trágyázatlan kontroll föparcella alacsony tavaszi N-szintjein (50-100 kg N/ha) ezzel az ,általános” tendenciával szemben, a trágyázási kísérletekben jól ismert ún. „hígulási” jelenség hatására a magtermés erőteljes tömeggyarapodását enyhe $\mathrm{N}$-tartalom csökkenés kísérte. Elöbbi $\mathrm{N}$-szinteken a magtömeg növekedése $\mathrm{C}$-tartalom növekedéssel (56,4\%-ról 57,4 \%-ra), és S-tartalom csökkenéssel (0,44\%-ról 0,42\%-ra ) párosult. A fejtrágyázás hatása a mag és a szalma $\mathrm{N}$-tartalmára egyaránt csak az 1. (kontroll) és a 2. föparcellán volt kimutatható.

A N-adagok növelése a szalma C- és S-tartalmát a magban tapasztaltakkal ellentétesen változtatta meg. A C-tartalom 52,8\%-ról 40,9\%-ra csökkent, a S-tartalom pedig $0,52 \%$-ról $0,7 \%$-ra nött. A N-trágyázás növelte a szár N/S arányát $(0,87$-ről 1,78-ra), s eröteljesen, csaknem harmadára csökkentette a $\mathrm{C} / \mathrm{N}$ arányt (92,65-ról 32,97-re). Ennél jóval kisebb volt a magtermésben a N/S (8,1-röl 9-re) és a C/N arány (16,5 röl 14,3-ra) változása.

A N-trágyázás hatását a vonatkozó irodalmi közlésekkel összevetve a következőket állapíthattuk meg. A N-trágyázás, kísérletünk egészét értékelve - a szakirodalmi eredményektől eltérően (JANZEN \& BETTANY, 1984; ZHAO et al., 1993; MCGRATH \& ZHAO, 1996) - nem csökkentette a repcemag S-tartalmát. A jelenség magyarázata lehet esetünkben a magtelítődés idején is jó S-ellátottság. A másik megfigyelés, mely szerint a szalma, azaz a szár és a becő együttes mintájának magasabb volt a S-tartalma $(0,70 \%)$, mint a magé $(0,45 \%)$, összeegyeztethető a szakirodalmi adatokkal. Ez az eredmény egyrészt utal a kén kismértékủ átépülésére, melyet többek között MENGEL (1976), HOCKING (1994) és SCHERER (2001) fogalmaztak meg, továbbá a nagyobb S-tartalmú növényi részek (becő és levél) (JANZEN \& BETTANY, 1984) nagyobb arányára a szalmában. E jelenségnek több oka is lehet, az egyik a fajta, a másik az ökológiai hatásokra visszavezethető gyors magtelítődés és érés.

\section{N/S arány alakulása $N$-kezelés hatására}

Az öszi káposztarepce föld feletti részeinek a N/S arányát elsődlegesen a növényi rész és a fejlődési állapot határozta meg, azonban értéke jelentősen nőtt a $\mathrm{N}$ kezelés hatására is. Általánosságban, a szakirodalmi eredményekkel teljesen egyező eredményeket kaptunk. A levél N/S aránya minden mintavételkor alacsonyabb volt, mint a száré, $s$ mindkét növényi rész $\mathrm{N} / \mathrm{S}$ aránya nagymértékben csökkent a tenyészidőszak során. A legmagasabb N/S arány a szárbaindulás kezdetén mintázott szárat jellemezte (átlagosan: 8,2, maximum: 10,7), a legalacsonyabb pedig betakarításkor a szalmát $(0,86-1,78)$. A levél N/S aránya jóval kisebb változással az áprilisi átlagosan 5,3-ról virágzás idejére átlagosan 4,5-re csökkent. A levél legmagasabb N/S aránya a tavasz folyamán 7,4 volt, virágzáskor pedig 5,2.

Hazai körülmények között más növényfajokra vonatkozóan végeztek hasonló méréseket. Jelentősen magasabb, 11-16 közötti N/S arányt talált az őszi búza vegetatív részeiben LÁszTITY (1991), a búzaszemben 13,5-15 közöttit GYŐRI és SíPOS 
(2004), míg a fükeverék szénatermésének 7-9 közötti N/S aránya RAGÁLYI és KÁDÁR (2006) kísérletében már jobban közelíti a repcére vonatkozó adatainkat.

Betakarításkor a két növényi részben (mag és szalma) a N/S arány egymástól alapvetően eltért, ugyanakkor mindkettő igen szük határok között mozgott. A magot 7,81 és 9,05 közötti, a szalmát - alacsony N-tartalma miatt - 0,86-1,78 közötti értékek jellemezték. A N-adagok az arányt kismértékben növelték.

Kísérletünk mind a virágzáskori levél S-tartalmára (határérték: $>6,5 \mathrm{mg} / \mathrm{g}$ SCHNUG és HANEKLAUS (1998) alapján), mind N/S arányára vonatkozóan kedvező S-ellátást jelzett. Ezt támasztja alá valamennyi, a repcére elfogadottnak tekinthető kritikus érték, így az ismert N/S arányok jóval magasabbak adatainknál. A legismertebb határértékek a vegetatív szakaszban levő teljes repcehajtásra vonatkozóan: SPENCER és munkatársai (1984) szerint $<20$, a virágzáskori levélre vonatkozóan pedig BAILEY (1986) alapján <14,8, SALBACH (1972) szerint pedig 10 körüli érték (10-14). Hasonlóan jók repcekísérletünk értékei a mag N-tartalmára ( $>3 \%$ körül), vagy S-tartalmára ( $>0,36 \%$ PINKERTON et al., 1993 alapján). Mégis az értékelés során fel kell hívnunk a figyelmet a május eleji időszak száraz időjárásának elemtartalmat befolyásoló lehetséges következményeire is.

\section{A magtermés $N$-, $C$ - és S-mennyisége}

A magterméssel kivont $\mathrm{N}$ - és S-mennyiség, továbbá a magtermésben akkumulálódott $\mathrm{C}$-mennyiség gyakorlatilag a magtermés nagyságát követve változott. $\mathrm{A} \mathrm{N}$ kezelések hatására a kivont N-mennyiség $23,5 \mathrm{~kg} /$ ha-ról $80 \mathrm{~kg} / \mathrm{ha}$-ra, a S-mennyiség pedig 4,3 kg/ha-ról 10,1 kg/ha-ra emelkedett. A kísérletben a legnagyobb magtermés a kontrollnak 3,4-szerese volt, hasonló arányban nött a kivont $\mathrm{N}$-mennyiség is. A növekvő magterméssel enyhén csökkenő S-tartalom miatt, a kivont S-mennyiség a N-trágyázás hatására kisebb mértékben (2,3-szeresre) nőtt.

A N-trágyázás legnagyobb mértékben a C-mennyiséget növelte, hatására a magtermésben $287 \mathrm{~kg} / \mathrm{ha}$-ról $1256 \mathrm{~kg} / \mathrm{ha}$ nőtt a szén mennyisége. Ez, a kontrollparcellához viszonyítva 4,4-szeres növekedés, egyértelmüen jelezte azt, hogy a növény jó $\mathrm{N}$-ellátása nemcsak a $\mathrm{CO}_{2}$-megkötést segíti, hanem növeli a magtermésbe juttatott $\mathrm{C}$-mennyiséget is. A magtermésben akkumulált $\mathrm{N}$-, S- és C-mennyiség legmagasabb értékét a 250-350 kg N/ha adagoknál mutatta, ez volt az „optimumgörbe” maximuma. Az ennél nagyobb N-trágyaadagok, különösen a 4/3-5 kezelésekben, a magterméssel kivont elemmennyiségeket csökkentették. A magterméssel kivont Nmennyiség $23-80 \mathrm{~kg} / \mathrm{ha}$, a S-mennyiség $4-10 \mathrm{~kg} / \mathrm{ha}$ volt.

A N mennyisége kevesebb, mint a KÁDÁR (2002) által megadott $55 \mathrm{~kg} \mathrm{~N} / \mathrm{t}, \mathrm{s}$ kevesebb FisMES és munkatársai (2000) franciaországi kísérleti adatainál is. A kísérletünk eredményeként kapott viszonylag alacsony N-mennyiség egyértelmúen nem a N-tartalom csökkenésére, hanem a magtermés szintjére vezethető vissza.

A N-tartalommal ellentétesen a magterméssel kivont $\mathrm{S}$ mennyisége inkább jó Sellátást jelez, hiszen 1,3-2-szerese FISMES és munkatársai (2000) eredményének. Hangsúlyoznunk kell azonban a két kísérlet meghatározó különbségét, a francia kísérletben S-hiányos talajon vizsgálták az együttes N- és S-trágyázás mellett kivont N- és S-mennyiséget. 


\section{Összefoglalás}

Az őszi káposztarepce (Brassica napus L. subsp. napus) nagy N- és S-igénye számos hazai és külföldi tanulmányból ismert. Ezért a repce okszerü tápanyagellátását célzó $\mathrm{N}$-trágyázási tartamkísérlet vizsgálatait kiterjesztettük a S-tartalom, a N/S arány, s előzőeken túl a N-trágyázás növényi C-tartalomra gyakorolt hatásának, a $\mathrm{C} / \mathrm{N}$ arány változásának jellemzésére.

A kísérletet Nagyhörcsökön mészlepedékes csernozjom talajon végeztük 20032004-ben, egy N-trágyázási tartamkísérlet részeként. Az őszi N-adagok a kísérlet föparcelláin (jelölésük 1-4.): 0, 75, 150 és $225 \mathrm{~kg} \mathrm{~N} /$ ha, a tavasziak pedig a főparcellán kialakított alparcellákon (jelölésük 1-5.): 0, 50, 100, 150 és $200 \mathrm{~kg} \mathrm{~N} / \mathrm{ha}$ voltak. Az egyes föparcellák $\mathrm{NO}_{3}-\mathrm{N}$-tartalma a kísérlet kezdetekor a tartamkísérlet hatásaként már jelentősen különbözött. A föparcella hatásában így a talaj kezdeti $\mathrm{NO}_{3}-\mathrm{N}$-tartalma és az őszi N-adag együttesen érvényesült, s határozta meg a tavaszi fejtrágya hatásosságát.

A maximális (2 $\mathrm{t} / \mathrm{ha})$ termést a talaj növekvő $\mathrm{NO}_{3}$-tartalmának megfelelően, egyre kisebb újabb mütrágyaadag kijuttatásával értük el. A N-adagok megbízhatóan csak az 1. és 2. főparcellán változtatták meg a termés mennyiségét, továbbá annak $\mathrm{N}$-, S- és C-tartalmát.

Kísérletünk valamennyi mutatóra, a virágzáskori levél és a mag N- és Startalmára, a levél N/S arányára vonatkozóan kedvező S-ellátást jelzett. A levél átlagosan 0,97\%-os és a mag 0,43\%-os S-tartalma magasabb, a levél átlagosan 4,5es N/S aránya pedig az ismert határértéknél jóval alacsonyabb volt.

Az eredmények alapján megállapítható volt, hogy a repce jó S-ellátását a mészlepedékes csernozjom talaj biztosította. Eredményeink megerősítették a N-trágyázás termés mennyiséget meghatározó szerepét, s jelezték - adott ökológiai feltételek között - a repcetermés további növekedésében a vízellátás fontosságát.

Kulcsszavak: repce, N-trágyázás, N-tartalom, S-tartalom, C-tartalom

A kísérleteket támogatta az Országos Tudományos és Kutatási Alap (T 033012, T 042778, T 046983 sz. pályázatok).

\section{Irodalom}

BAILEY, L. D., 1986. The sulphur status of Eastern Canadian prairie soils: Sulphur response and requirements of alfalfa (Medicago sativa L.), rape (Brassica napus L.) and barley (Hordeum vulgare L.) Can. J. Soc. Sci. 66. 209-216.

BloEM, E. et al., 2004. Sulphur supply and infection with Pyrenopeziza brassicae influence L-cysteine desulphydrase activity in Brassica napus L. J. Experimental Botany. 55. 2305-2312.

CECotTI, S. P., 1996 Plant nutrient sulphur - a review of nutrient balance, environmental impact and fertilizers. Fertil. Res. 43. 117-125. 
FISMES, J. et al., 2000. Influence of sulfur on apparent N-use efficiency, yield and quality of oilseed rape (Brassica napus L.) grown on a calcareous soil. European Journal of Agronomy. 12. 127-141.

GYÖRI, Z. \& SÍPOS, P., 2004. Changes of quality parameters of winter wheat at maturing. Int. Workshop, Modelling Quality traits and their genetic variability for wheat. 18-21 July 2004, Clermon-Ferrand, France. (P2)

HockING, P. J., 1994. Dry matter production, mineral nutrient concentration and nutrient distribution and redistribution in irrigated spring wheat. J. Plant Nutr. 17. 1289-1308.

JANZEN, H. H. \& BetTANy, J. R., 1984. Sulfur nutrition of rapeseed. I. Influence of fertilizer nitrogen and sulfur rates. Soil Sci. Soc. Am. J. 48. 100-107.

LAKANEN, E. \& ERVIÖ, R., 1971. A comparison of eight extractants for the determination of plant available micronutrients in soils. Acta Agr. Fenn. 123. 223-232.

LÁSZTITY B., 1991. Az NPK tápanyagellátás hatása az őszi búza kéntartalmának és felhalmozásának dinamikájára. Agrokémia és Talajtan. 40. 131-139.

KÁDÁR I., 2002. A repce (Brassica napus L.) tápláltsági állapotának megítélése növényanalízissel. Agrokémia és Talajtan. 51. 395-416.

KÁDÁR I. et al., 2001. A repce (Brassica napus L.) műtrágyázása vályog csernozjom talajon. I. Növénytermelés. 50. 559-573.

MÁTHÉNÉ GÁspÁr G., VetTer J. \& SzŐCs Z., 2001. Amaránttörzsek zöldhozama és szárazságtürése. Növénytermelés. 50. 431-439.

MCGRATH, S. P. \& ZHAO, F. J., 1996. Sulphur uptake, yield responses and the interactions between nitrogen and sulphur in winter oilseed rape (Brassica napus). J. Agr. Sci. 126. 53-62.

Mengel, K., 1976. A növények táplálkozása és anyagcseréje. Mezőgazdasági Kiadó. Budapest.

NÉMETH T., 1987-1988. Az őszi káposztarepce tápelemfelvétele és trágyázása. Agrokémia és Talajtan. 36-37. 294-312.

NÉMETH T., 1988. A N-ellátottság szerepe az őszi káposztarepce termesztésében. Kandidátusi értekezés. Budapest

NÉMETH T. \& KARAMÁN J., 1986. A N-trágyázás hatása az őszi káposztarepce termésére és tápelemtartalmára. Agrokémia és Talajtan. 35. 95-104.

PINKERTON, A. et al., 1993. A preliminary assessment of plant analysis for diagnosis of sulphur deficiency in canola. In: $9^{\text {th }}$ Australian Res. Assembly on Brassicas, Wagga Wagga, New South Wales, October 5-7, 1993. (Eds.: WratTEN, N. \& MAILER, R. J.) 21-28.

RAGÁLYI, P. \& KÁDÁR, I., 2006. Effect of NPK fertilisation on the yield and mineral element content of an established all-grass. Agrokémia és Talajtan. 55. 155-164.

Reuter, D. J. \& Robinson, J. B. (Eds.), 1997. Plant Analysis. $2^{\text {nd }}$ ed. Australian Soil and Plant Analysis Council Inc., CSIRO Publ. Collingwood, Australia.

SALBACH, E., 1972. Über die Schwefelbedarf landwirtschaftlicher Nutzpflanzen. Land. Forsch. 27. (1) 224-228.

SCHERER, H. W., 2001. Sulphur in crop production. European Journal of Agronomy. 14. 81-101.

Schnug, E. \& Haneklaus, S., 1998. Diagnosis of sulphur nutrition. In: Sulphur in Agroecosystems. (Ed.: ScHNUG, E.) 1-38. Kluwer Academic Press. Dordrecht. The Netherlands. 
Spencer, K., Freney, J. R. \& Jones, M. B., 1984. A preliminary testing of plant analysis procedures for the assessment of the sulphur status of oiseed rape. Aust. J. Agric. Res. 35. 163-175.

SUNARPI \& ANDERSON, J. W., 1997. Effect of nitrogen nutrition on the export of sulphur from leaves in soybean. Plant and Soil. 188. 177-187.

ZHAO, F. et al., 1993. Influence of sulphur and nitrogen on seed yield and quality of low glucosinolate oilseed rape (Brassica napus L.). J. Sci. Food Agr. 63. 29-37.

Érkezett: 2007. február 9. 


\title{
Changes in the $\mathbf{N}, \mathrm{C}$ and $\mathrm{S}$ contents of canola in response to $\mathbf{N}$ fertilization on calcareous chernozem soil
}

\author{
${ }^{1}$ G. MÁTHÉ-GÁSPÁR, ${ }^{1}$ L. RADIMSZKY, ${ }^{2} Z$. GYÖRI, ${ }^{3}$ A. HÜVELY and ${ }^{1}$ T. NÉMETH
}

${ }^{1}$ Research Institute for Soil Science and Agricultural Chemistry of the Hungarian Academy of Sciences, Budapest; ${ }^{2}$ Department of Product Processing and Quality Control, University of Debrecen, Debrecen and ${ }^{3}$ Faculty of Horticulture, Kecskemét College, Kecskemét (Hungary)

\section{Summary}

The high $\mathrm{N}$ and $\mathrm{S}$ requirements of canola (Brassica napus L. subsp. napus) have been widely reported. Long-term experiments on the $\mathrm{N}$ fertilization of canola were thus expanded to include the determination of $\mathrm{S}$ contents and N/S ratios, and to analyse the effect of $\mathrm{N}$ fertilization on plant $\mathrm{C}$ contents and changes in the $\mathrm{C} / \mathrm{N}$ ratio.

The experiments were carried out on calcareous chernozem soil in Nagyhörcsök in 2003 and 2004, as part of a long-term $\mathrm{N}$ fertilization experiment. The $\mathrm{N}$ rates applied to main plots $1-4$ in autumn were $0,75,150$ and $225 \mathrm{~kg} \mathrm{~N} / \mathrm{ha}$, while those given to subplots $1-5$ in spring were $0,50,100,150$ and $200 \mathrm{~kg} \mathrm{~N} / \mathrm{ha}$. At the start of the experiment the $\mathrm{NO}_{3}-\mathrm{N}$ contents of the main plots already differed substantially due to the effect of the long-term treatments. The effect of the main plots, which influenced the effectiveness of topdressing in spring, was thus a combination of the initial soil $\mathrm{NO}_{3}-\mathrm{N}$ content and the $\mathrm{N}$ rate applied in autumn. As the $\mathrm{NO}_{3}$ content of the soil increased, the additional fertilizer rate required to obtain maximum yield $(2 \mathrm{t} / \mathrm{ha})$ declined. The $\mathrm{N}$ rates only had a significant effect on the yield, and on the N, S and C contents of the yield in main plots 1 and 2 .

Favourable S supplies were indicated by all the parameters studied in the experiment, including the $\mathrm{N}$ and $\mathrm{S}$ contents of the seeds and the N/S ratio of the leaves. The average $0.97 \% \mathrm{~S}$ content in the leaves and $0.43 \%$ in the seeds was higher than the accepted limit values, while the average $4.5 \mathrm{~N} / \mathrm{S}$ ratio in the leaves was considerably lower.

It could be concluded from the results that the calcareous chernozem soil provides good $\mathrm{S}$ supplies for canola. The results confirmed the decisive role of $\mathrm{N}$ fertilization in the yield level and indicated the importance of the water supplies in achieving further increases in yield under the given ecological conditions.

Table 1. Shoot mass of canola in main plots $1-4$ in response to $\mathrm{N}$ fertilization in samples taken in spring and summer. (1) Sampling date, year, month, day. (2) Development stage of canola: a) end of rosette stage; b) beginning of shooting; c) beginning of flowering; d) full maturity. (3) Air-dry shoot mass on the main plots, g/10 plants. (4) Mean. (5) $\mathrm{LSD}_{5 \%}$.

Table 2. Seed yield ( $\mathrm{t} / \mathrm{ha}$ ) of canola in response to various $\mathrm{N}$ rates. (1) Subplots, N rates applied in spring. a) $\mathrm{LSD}_{5 \%}$. (2) Main plots, $\mathrm{N}$ rates applied in autumn.

Table 3. Effect of $\mathrm{N}$ treatments on the element contents of aboveground canola organs at the end of the rosette stage, the beginning of shooting and the beginning of flowering in the main plots. (1) Element. (2) Plant organ. a) stem, b) leaf. (3) Element content in the main plots as the result of $\mathrm{N}$ treatments, \%. (4) Mean. (5) $\operatorname{LSD}_{5 \%}$.

Table 4. Effect of $\mathrm{N}$ fertilization on the N, C and $\mathrm{S}$ contents of the seed and straw yields of canola at harvest (12 July 2004). (1): see Table 2. (2) Seed. (3) Straw. 